\title{
Politics of climate change: discourses of policy and practice in developing countries
}

\section{Editorial}

The past twenty years has witnessed a momentous surge in interest in the idea of climate change. Much of this growth is due to the field of climate science, which has produced compelling evidence to show that human actions are significantly changing the composition of the atmosphere, which is altering the functioning of the climate system (IPCC, 2007). It is also attributable to the tens of thousands of organisations, networks, companies, consultants and advocates concerned with a host of climate change-related response issues, ranging from energy and infrastructure, to risk management and reduction, to community-based adaptation that have been spawned as a result. Many of these actors are supported by major financial investments. For example, in March 2010 the UK Department for International Development (DFID) announced that it would be investing $£ 50$ million in a new programme, the Climate and Development Knowledge Network (CDKN), to "help developing countries navigate the challenges of climate change". This trend is set to continue with tens of billions of dollars of climate finance pledged by the international community over the next ten years (COP, 2009). In this way, climate change has become "one of the defining contemporary international development issues" (Tanner and Allouche, 2011, 1).

Studies of contemporary climate change from greenhouse gas emissions and land use changes originated in the natural sciences-based literature and the science-based institutions of the United Nations, particularly the Intergovernmental Panel on Climate Change (IPCC). This purely physical framing of the climate change issue adopted by the IPCC has dominated policy-making since the mid 1980s (Hulme, 2007) and associated concepts - most notably 'mitigation' and 'adaptation' - have quickly garnered legitimacy in international debates (McNamara and Gibson, 2009). However, in recent years, mounting efforts by the international policy community to link climate change interventions to human development goals that reduce poverty and promote equity have been challenged on the grounds that they systematically underplay critical cultural, socioeconomic, historic and political dimensions of human societies (Gaillard, 2010, Mercer, 2010, Marino and Ribot, 2012, Farbotko and Lazrus, 2011). Mike Hulme, founding director of the world-renowned Tyndall Centre for Climate Change Research, has taken up this theme, writing in 2007 that a re-examination of climate change as a cultural concept is urgently required, one that starts with contributions from the interpretive humanities and social sciences, particularly geography, and is informed by 
understanding of how knowledge, power and scale interact (Hulme, 2007). This is important because "the dominating construction of climate change as an overly physical phenomenon" readily allows it "to be appropriated uncritically in support of an expanding range of ideologies" (p.9).

This Themed Section aims to address this concern by increasing understanding of how the idea of climate change, and the policies and actions that spring from it, travel beyond their origins in natural sciences to meet different political arenas in the developing world. Earlier work by scholars to draw attention to the political dimensions of climate change has focussed on the political economy (Tanner and Allouche, 2011) or the 'everyday' political realms of societal perceptions and social institutions (Artur and Hilhorst, 2011). The approach taken in this edition primarily concerns the climate change phenomenon as a discursive concept operating across international, national and sub-national scales. Discourse, as it is understood here, is concerned with the interweaving of knowledge and power (Foucault, 1979), and the messages, narratives and policy prescriptions that emanate from this intersection (Adger et al., 2001). From an analytical perspective, discourse is the set of social mechanisms through which the constructivist challenge has been levelled at positivism (Wilson, 2006). Discourse is particularly pertinent to the study of climate change because it provides a framework that is sensitive to the political construction and use of scientific knowledge. This is particularly timely given that international and national efforts to implement climate change mitigation and adaptation measures are coming under intense inspection by media, civil society, and a wide range of governmental and private sector interests (Anon, 2010).

In the field of environment and development, a concern with how people imagine humanclimate interactions and therefore begin to build images or narratives about particular groups of people, geographical places or periods of time is not new (cf. Furedi, 2007, Endfield and Nash, 2002). Some scholars view these types of cultural conception as hegemonic, in the sense that they dominate thinking and structure institutional arrangements. For example, Bankoff $(2001,19)$, examining the historical roots of the 'hazard' discursive framework, argues that "tropicality, development and vulnerability form part of one and the same essentialising and generalising cultural discourse that denigrates large regions of the world as disease-ridden, poverty-stricken and disaster-prone", thus justifying Western intervention. Others scholars, however, see a greater plurality of images and narratives in which discourses 
example, is used by McNamara and Gibson (2009) who show how the dominant representation of people living the Pacific as 'climate refugees' by the international climate change community has been resisted by the islanders themselves, many of whom do not accord with the action of 'fleeing' as part of their vision for the future.

The papers presented in this Themed Section reflect both the hegemonic and more pluralistic positions outlined above. The articles are mostly case study-based and focus on sub-Saharan Africa and Small Island Developing States (SIDS), which are considered to be amongst the most vulnerable regions to climate change in the world (Christensen et al., 2007). The articles are organised around three interlinked themes. The first theme concerns the processes of rapid technicalisation and professionalisation of the climate change 'industry'. According to Escobar, development has "fostered a way of conceiving of social life as a technical problem, as a matter for rational decision and management to be entrusted to the group of people - the development professionals - whose specialised knowledge allegedly qualifies them for that task" (Escobar, 1997, 91). The effect of these processes is that the terms of the international development debate are substantially narrowed as "the separation between 'expert' and 'local' knowledge and intellectual distance between donor and recipient is maintained", and potentially critical discourses are co-opted (Kothari, 2005, 428). Similarly, climate change 'experts' operating within international policy circles have been criticised for utilising an increasingly 'managerial' approach to climate change policy, and therefore narrowing the boundaries of what can be viewed as legitimate social action in response to the problem (Skoglund and Jensen, 2013, Few et al., 2007). These concerns are taken up in this issue by Sasser (2013) who shows how one particular managerial 'solution' to the climate change problem that focuses on demographics and population control has had the effect of "narrowing understandings of sexual and reproductive health and rights (SRHR) issues for women through the technicalisation of [their] rights". Weisser et al. (2013), also in this issue, further develop this theme by demonstrating how 'expert-defined', 'mechanistic' interpretations of climate change adaptation operating in international policy circles are understood, contested and reinvented by multiple actors operating at national and subnational levels.

The second theme deals with the ideological effects of the climate change industry, which is 'depoliticisation'. This term is most associated with Ferguson (1994, xv) who likened development in Lesotho to an 'anti-politics machine', "depoliticising everything that it 
touches", by depriving the subjects of anti-poverty interventions of their history and politics. More recently, efforts by donors to incorporate new approaches and techniques that attempt to reverse the top-down hegemony of development agencies, such as participation, have similarly come under attack (cf. Cooke and Kothari, 2001, Hickey and Mohan, 2005). This is evident from the large body of case studies showing how 'one-size-fits-all development recipes' that focus on concepts that everyone can ostensibly agree on, such as 'empowerment', deflect attention away from the political reforms needed for structural change (Cornwall and Brock, 2005, Botchway, 2001). Recently, Felli and Castro (2012) have argued that the high-profile Foresight Report on Migration and Global Environmental Change (Foresight: Migration and Global Environmental Change, 2011) has shifted analytical attention away from the socioeconomic and political context to refocus it onto the individual's qualities and his or her 'capacity to adapt'. Similarly, this Themed Section argues that a focus on climate change by researchers, policy-makers and practitioners can deflect attention away from underlying political conditions of vulnerability and exploitation towards the nature of the physical hazard itself, be it drought, flood or some other environmental perturbation. Kelman (2013), for example, argues in this issue that, in the context of SIDS, the fundamental challenge that islanders face is not so much the hazard of climate per se, but why SIDS peoples often do not have the resources or options to resolve climate change and other development challenges themselves, on their own terms.

The third theme concerns the institutional effects of an insufficiently socialised idea of climate change, which is the maintenance of existing relations of power or their reconfiguraftion in favour of the already powerful. Climate change mitigation and adaptation are complex, contested concepts that have spawned a wide range of policies and interventions across the developing world, ranging from infrastructure development, to agricultural extension, to resettlement of populations considered to be at risk of climate-related hazards (Kelman, 2010). The flexibility of the mitigation and adaptation paradigms might be considered by some as a sign of the concepts' strengths. However, as pointed out by Hulme (2007), such properties also endow them with a near "infinite plasticity...a malleable envoy enlisted in support of too many rulers" (pp.9-10). In this issue, Arnall (2013) and Kothari (2013) demonstrate how these processes have come to pass in the cases of Mozambique and the Maldives respectively. The authors show how climate change is being used in their respective countries to validate the re-emergence of past unpopular social policies, some of which might actually exacerbate vulnerability. The focus in both instances is on involuntary 
resettlement, an intervention that has received growing interest from the international policy community either as a potential climate change adaptation measure or as exemplifying a failure to adapt to climate change (Bogardi and Warner, 2008, Warner, 2011). However, as the papers demonstrate, resettlement is a deeply political process that raises fundamental questions about state-rural relations, and often results in unequal distribution of costs and benefits amongst relocated persons.

It is not the intention of this Themed Section to deny the seriousness of contemporary, human-induced climate change, nor the threat that it poses in different regions of the world. Rather, the aim is to demonstrate the multifarious ways in which climate science, as well as the international community that has built up around it, is both a set of political processes in its own right as well as the producer of political impacts in developing countries where its policies take influence, whether these effects are intended by the actors involved or not. This suggests that greater scrutiny of the discursive and political dimensions of mitigation and adaptation activities is required, with more attention being directed towards the policy consequences that governments and donors construct as a result of their framing and rendition of climate change issues. Such an approach will require constant questioning of the underlying epistemological and ethical assumptions underpinning and framing these debates, such as those relating to the ongoing discussion on global environmental change and migration (see Nicholson, 2013, this issue). It will also entail development of new methodological approaches, drawing upon ideas such as actor network theory and the concept of 'translation', to understanding climate change's imprecise but contested associated practices (Weisser et al., 2013). In this way, we might start to build a richer, more rounded picture of what contemporary climate change is, and what impacts it might have on people's lives, in developed and developing countries.

\section{References}

Adger, W N, Benjaminsen, A, Brown, K \& Svarstad, H 2001 Advancing a political ecology of global environmental discourses. Development and Change 32 681-715.

Anon 2010 Closing the Climategate. Nature 468345.

Arnall, A H 2013 A climate of control: flooding, displacement and planned resettlement in the Lower Zambezi River valley, Mozambique. Geographical Journal.

Artur, L \& Hilhorst, D 2011 Everyday realities of climate change adaptation in Mozambique. Global Environmental Change 22 529-36.

Bankoff 2001 Rendering the world unsafe: 'vulnerability' as a Western discourse. Disasters 25 19-35.

Bogardi, J \& Warner, K 2008 Here comes the flood. Nature Reports 138. 
Botchway, K 2001 Paradox of empowerment: reflections on a case study from northern Ghana World Development 29 135-53.

Christensen, J H, Hewitson, B, Busuioc, A, Chen, A, Gao, X, Held, I, Jones, R, Kolli, R K, Kwon, W-T, Laprise, R, Rueda, V M, Mearns, L, Menéndez, C G, Räisänen, J, Rinke, A, Sarr, A \& Whetton, P 2007 Regional Climate Projections. In: Climate Change 2007: The Physical Science Basis. Contribution of Working Group I to the Fourth Assessment Report of the Intergovernmental Panel on Climate Change. IPCC, Cambridge.

Cooke, B \& Kothari, U 2001 Participation: the new tyranny? Zed Books, London.

COP 2009 Copenhagen Accord. UNFCCC, Copenhagen

Cornwall, A \& Brock, K 2005 What do buzzwords do for development policy? A critical look at 'participation', 'empowerment' and 'poverty reduction'. Third World Quarterly 26 1043-60.

Endfield, G H \& Nash, D J 2002 Drought, desiccation and discourse: missionary correspondence and nineteenth century climate change in central southern Africa. The Geogrpahical Journal 168 33-47.

Escobar, A 1997 The making and umaking of the Third World through development. in Rahnema, M \& Bawtree, $\mathbf{V}$ eds The Post Development Reader. Zed Books, London.

Farbotko, C \& Lazrus, H 2011 The first climate refugees? Contesting global narratives of climate change in Tuvalu. Global Environmental Change 22 382-90.

Felli, R \& Castree, N 2012 Commentary: Neoliberalising adaptation to environmental change: foresight or foreclosure? Environment and PLanning A 44 1-4.

Ferguson, J 1994 The anti-politics machine: "development", depoliticization, and bureaucratic power in Lesotho University of Minnesota Press, Minneapolis; London

Few, R, Brown, K \& Tompkins, E L 2007 Public participation and climate change adaptation: Avoiding the illusion of inclusion Climate policy 7 46-59.

Foresight: Migration and Global Environmental Change 2011 Final Project Report. The Government Office for Science, London.

Foucault, M 1979 Discipline and punishment: the birth of the prison Penguin, Harmondsworth.

Furedi, F 2007 The changing meaning of disaster. Area 39 482-89.

Gaillard, J C 2010 Vulnerability, capacity and resilience: perspectives for climate and development policy. Journal of International Development 22 218-32.

Hickey, S \& Mohan, G 2005 Towards participation as transformation: critical themes and challenges. in Hickey, S \& Mohan, G eds Participation: from tyranny to transformation? Exploring new approaches to participation in development. Zed Books London

Hilhorst, D 2001 Village experts and development discourse: "progress" in a Philippine Igorot village. Human Organisation 60 401-13.

Hulme, M 2007 Geographical work at the boundaries of climate change. Transactions of the Institute of British Geographers 33 5-11.

IPCC 2007 Summary for Policymakers. in Parry, M L, Canziani, O F, Palutikof, J P, van der Linden, P J \& Hanson, C E eds Climate Change 2007: Impacts, Adaptation and Vulnerability. Contribution of Working Group II to the Fourth Assessment Report of the Intergovernmental Panel on Climate Change. Cambridge University Press, Cambridge.

Kelman, I 2010 Introduction to climate, disasters and international development. Journal of International Development 22 208-17.

Kelman, I 2013 No change from climate change: vulnerability and small island developing states. The Geographical Journal.

Kothari, U 2005 Authority and expertise: the professionalism if international development and the ordering of dissent. Antipode 37 424-45. 
Kothari, U 2013 Climate change and migration: a political discourse of resettlement in the Maldives. The Geographical Journal.

Marino, E \& Ribot, J 2012 Special Issue Introduction: Adding insult to injury: Climate change and the inequities of climate intervention. Global Environmental Change 22323 28.

McNamara, K E \& Gibson, C 2009 'We do not want to leave our land': Pacific ambassadors at the United Nations resist the category of 'climate refugees'. Geoforum 40 475-83.

Mercer 2010 Disaster risk reduction or climate change adaptation: are we reinventing the wheel? Journal of International Development 22 247-64.

Nicholson, C T M 2013 Climate change and the politics of causality: the case of climate change and migration. Geographical Journal.

Sasser, J 2013 The wave of the future? Youth advocacy at the nexus of population and climate change. The Geographical Journal.

Skoglund, A \& Jensen, T 2013 The Professionalization of Ethics in the Intergovernmental Panel on Climate Change (IPCC): From Servant of Science to Ethical Master? . Sustainable Development 21 122-30.

Tanner, T \& Allouche, J 2011 Towards a new political economy of climate change and development. IDS Bulletin 42 1-15.

Warner, K 2011 Migration and displacement in the context of adaptation to climate change: developments in the UNFCCC climate negotiations and potential for future action. Migration and Global Environmental Change. Government Office for Science, London.

Weisser, F, Bollig, M, Doevenspeck, M \& Muller-Mahn, D 2013 Translating the 'adaptation to climate change' paradigm - the politics of a travelling idea in Africa.

Wilson, G 2006 Beyond the technocrat? The professional expert in development practice. Development and Change 37 501-23. 